Table of Contents / Table des matières

Editorial

ELI MACLAREN

Teachers Must Read: Imagining and Instructing the

Teacher-as-Reader in Nineteenth-Century English Canada HEATHER MURRAY

"Nearer to the Exercises of Heaven": Nineteenth-Century

Maritime Presbyterians and The Choir

CREIGHTON BARRETT AND BERTRUM H. MACDONALD

The Giller Prize (1994-2004) and Scotiabank Giller Prize (2005-2014): A Bibliography

ANDREW DAVID IRVINE

The Fragmented Armada: The Transmission of an

Armada News Pamphlet

MEAGHAN J. BROWN

\title{
Books in Review / Comptes rendus
}

ALISON RUKAVINA and/et RUTH-ELLEN ST. ONGE

Frédéric Barbier. Histoire des bibliothèques. D'Alexandrie

aux bibliothèques virtuelles

(Marie-Claude Felton)

Pierre Hébert, Patricia Godbout, Richard Giguère, avec la collaboration de Stéphanie Bernier. La correspondance entre Louis Dantin et Alfred DesRochers. Une émulation littéraire (I928-1939) (Julie St-Laurent)

Marie-Claude Felton. Maîtres de leurs ouvrages: l'édition à compte d'auteur à Paris au XVIII siècle (Christina Ionescu)

Christine Rivalan Guégo et Miriam Nicoli (dir.). La collection. Essor et affirmation d'un objet éditorial (Philippe Rioux)

Nouveaux aspects de la culture de l'imprimé. Questions et perspectives $X V^{e}-X V I I^{e}$ siècles. Études réunies par Grégoire Holtz (Lyse Roy) 
Brenda Dunn-Lardeau (dir.). Ouvrages phares de la Réforme et de la Contre-Réforme dans les collections montréalaises (Jean-François Vallée)

Revue de Bibliothèque et Archives nationales du Québec, no. 5, 2013 (Svetlana Kochkina)

Melanie Bigold. Women of Letters, Manuscript Circulation, and Print Afterlives in the Eighteenth Century: Elizabeth Rowe, Catherine Cockburn, and Elizabeth Carter (Ann-Marie Hansen)

Richard Clay. Iconoclasm in Revolutionary Paris. The Transformation of Signs (Ruth-Ellen St. Onge)

Sean Grass. Charles Dickens's "Our Mutual Friend": A Publishing History (Pamela Casey)

Zoe Jaques and Eugene Giddens. Lewis Carroll's "Alice's Adventures in Wonderland" and "Through the Looking Glass": A Publishing History (Gillian Fenwick)

Lise Jaillant. Modernism, Middlebrow and the Literary Canon: The Modern Library Series, I9I7-I955 (Kristine Smitka)

Catherine M. Parisian. Frances Burney's "Cecilia":

A Publishing History (Leigh Bonds)

Valerie Purton, ed. Darwin, Tennyson and Their Readers:

Explorations in Victorian Literature and Science (Erin N. Bistline)

Solveig Robinson. The Book in Society: An Introduction to Print Culture (Joya Mannan)

Konstantinos Sp. Staikos. The History of the Library in Western Civilization. Vol. 5, From Petrarch to Michelangelo: The Revival of the Study of the Classics and the First Humanistic Libraries Printing in the Service of the World of Books and Monumental Libraries (Ravit H. David)

Information for Authors / Information à l'intention de nos collaborateurs 